\title{
ABOUT THE BORDER BETWEEN TWO PHYLOGROUPS OF THE COMMON HAMSTER (CRICETUS CRICETUS) (CRICETINAE, RODENTIA)
}

\author{
Natalia Yu. Feoktistova ${ }^{1}$, Ilya G.:Meschersky ${ }^{1}$, Pavel L. Bogomolov ${ }^{1}$, \\ Sergey I. Meschersky ${ }^{1}$, Alexandra S. Sayan ${ }^{1}$, Elena F. Sitnikova ${ }^{2}$, \\ Andrey A. Vlasov ${ }^{3}$, Olga P. Vlasova ${ }^{3}$, and Alexey V. Surov ${ }^{1}$ \\ ${ }^{1}$ A. N. Severtsov Institute of Ecology and Evolution, Russian Academy of Sciences \\ 33 Leninsky Prosp., Moscow 119071, Russia \\ E-mail:feoktistovanyu@gmail.com \\ ${ }^{2}$ State Nature Biosphere Reserve "Bryansky Les" \\ St. Nerussa, Suzemsky District, Bryansk Region 242180, Russia \\ ${ }^{3}$ Central Chernozem Natural Reserve \\ Zapovednyi, Kursky District, Kursk Region 307028, Russia
}

Received 17 August 2018, revised 21 September 2018, accepted 2 October 2018

Feoktistova N. Yu., Meschersky I. G., Bogomolov P. L., Meschersky S. I., Sayan A. S., Sitnikova E. F., Vlasov A. A., Vlasova O. P., Surov A. V. About the Border between Two Phylogroups of the Common Hamster (Cricetus cricetus) (Cricetinae, Rodentia). Povolzhskiy Journal of Ecology, 2018, no. 4, pp. 485-494 (in Russian). DOI: https://doi.org/10.18500/1684-7318-2018-4-485-494

The Common hamster (Cricetus cricetus) is the rodent with one of the largest range (6 million $\mathrm{km}^{2}$ ). There were four phylogenetic lineages earlier recovered in Western Europe, Ukraine and Bryansk Province of Russia: "North", "Pannonia", E1 and E0. E1 was previously reported from South-Eastern Poland and Western Ukraine and never been found in sympatry with "Pannonia" although the closest distance between them was estimated as $20 \mathrm{~km}$. The question is whether the sympatry of E1 and E0 phylogroups exists? Special survey was arranged across Moscow, Tula, Bryansk, Oryol, Kursk, Voronezh and Lipetsk provinces to get the answer. Sequence analysis of the mtDNA control region and the cyt $b$ gene from the tissue samples was carried out in the common hamsters captured in these areas and their belonging to a certain phylogroup was determined. For the first time a case of sympatry was revealed - in the city of Mtsensk vicinity (Oryol province). Here we discovered hamsters the both lineages - E0 and E1 at the same habitat. Hypothetically E1/E0 ranges boundary runs from Ukrainian Sumy province to North-East by line dividing the Russian Kursk and Oryol provinces. The existence of subclades within both E1 and E0 phylogroups suggests that diversification of phylogenetic lineages of the Common hamster in Eastern Europe may result from not single but multiple climatic events during the second half of Late Pleistocene. The phylogeographic structure of the species in Eastern Europe may be more complex than it currently known.

Key words: Common hamster, phylogeography, mtDNA, lineages, control region, sympatry.

DOI: https://doi.org/10.18500/1684-7318-2018-4-485-494

\section{INTRODUCTION}

The Common hamster (Cricetus cricetus Linnaeus, 1758) has one of the largest ranges of all the Palearctic mammals. It extends appr. 6 million $\mathrm{km}^{2}$ from Belgium to China.

(C) Feoktistova N. Yu., Meschersky I. G., Bogomolov P. L., Meschersky S. I., Sayan A. S., Sitnikova E. F., Vlasov A. A., Vlasova O. P., Surov A. V., 2018 
Natalia Yu. Feoktistova, Ilya G.'Meschersky, Pavel L. Bogomolov et al.

The southernmost known point of the species range is $42^{\circ} 57^{\prime} \mathrm{N}$ (Ciscaucasia, North Ossetia Republic, Russia); the northernmost $-60^{\circ} 44^{\prime} \mathrm{N}$ (Perm Province, Russia). The easternmost known point is about $97^{\circ} \mathrm{E}$ (Krasnoyarsk province, Russia), and westernmost point is about $5^{\circ} \mathrm{E}$ (Belgium). Half of its range (appr. 3 million $\mathrm{km}^{2}$ ) situates in Russia. The Common hamster prefers forest-steppes and steppes habitats, but is strongly attracted by agriculture areas, vegetable gardens, and farm enterprises. In some areas (the Ural) it occurred in the southern and even middle taiga zone. In Siberia, the highest abundance of the species is recorded in the so-called "chernevaya taiga" ("black-taiga" mixed coniferous-deciduous forests). All these features testify for extremely wide adaptability of this species. At the same time the Common hamster is one of the most endangered mammals in Western and Central Europe (Surov et al., 2016).

Molecular genetic studies and phylogeographic analysis of the Common hamster populations was not only of considerable theoretical interest but also of practical value species restoration. Studies over the last $10-15$ years are numerous but apply only to the western region of the Common hamster range. In Western and Central Europe, based on mtDNA sequencing, two phylogenetic lineages of the Common hamster - Pannonia and North, were revealed (Neumann et al., 2005). However, some of mitochondrial haplotypes of hamsters from Russia and Poland known at the time could not be attributed to either one or another of the group. Later the distinctive haplotypes known from SouthEastern Poland and Western Ukraine were imputed to separated phylogroup named E1 (Banaszek et al., 2010, 2012; Korbut et al., 2013).

In our study concerning phylogeography of the Common hamster in Russia and Kazakhstan (Feoktistova et al., 2017) we discovered the single E1 haplotype in Bryansk province in Western Russia. Whereas more eastern territories of Western Russia, Volga region, Ural, and Northern Kazakhstan are populated by hamsters of another mitochondrial phylogroup, we named E0.

As it is currently known, ranges of Pannonia and E1 phylogroups of the Common hamster do not overlap. Attempts to detect the contact zone between these lineages failed although populations ranges located very close to each other (ab. $20 \mathrm{~km}$ ) (Banaszek et al., 2010).

In the present study, we focused on updating the ranges and finding possible sympatry Е0 и Е1 lineages in the Western part of Russia.

\section{MATERIAL AND METHODS}

In June 2017 and 2018 we conducted route surveys in the Bryansk, Oryol, Kursk, Voronezh, Lipetsk, Tula and Moscow provinces of Russia to collect tissue samples and determine the number and preferred habitats of the Common hamster in this area. During the route, we took interviews of the local people, showed them the animal photos.

We caught the hamsters with live traps. Ten localities in Western and Central parts of European Russia are shown on Figure 1 and described in Table 1. As a total, 25 hamsters were caught at this area in 2017 and 2018. Additionally, we analyzed new samples from Crimea (22 hamsters from Simferopol city and its suburbs, suburbs of Sevastopol city, Stary Krym and Pervomaiske village in Kirovsky district), and from Northern Kazakhstan (6 hamsters from Astana city, Akmola and Karagandy provinces).

The captured animals were anesthetized with a veterinary drug (Zoletil) and a small fragment of the ear skin picked for genetic analysis. Also, as an outgroup, we analyzed a 
sample of the Common hamster from Pleven province of Bulgaria, kindly provided by Dr. Nedko Nedyalkov (National Museum of Natural History of Bulgaria).

As markers of phylogenetic lineages, we used sequences of mitochondrial control region and cytochrome $b$ (cyt $b$ ) gene. DNA extraction and amplification were done according to the method described earlier (Feoktistova et al., 2017). The sequences were obtained using the BigDye Terminator v. 3.1 kit and sequencing on a Genetic Analyzer 3500 (Thermo Fisher Scientific). Quality control of the automatic decoding of chromatograms, the merging of forward and reverse individual sequences, and their alignment and storage was completed using BioEdit v.7.2.5 software (Hall, 1999). The sequences revealed for the first time were deposited in GenBank as MK202453-469 (cyt $b$ ) and MK202471-480 (control region).

Table 1. The sampling localities in Western and Central Russia

\begin{tabular}{|c|c|c|c|c|}
\hline $\begin{array}{c}\text { No. } \\
\text { of locality }\end{array}$ & Definition & Coordinates & $\begin{array}{c}\text { Number } \\
\text { of animals* }\end{array}$ & $\begin{array}{l}\text { Number of } \\
\text { haplotypes }\end{array}$ \\
\hline 1 & Western Russia, Bryansk province, 6 km N Sevsk city & $52^{\circ} 12^{\prime} \mathrm{N} 34^{\circ} 31^{\prime} \mathrm{E}$ & $4(3)$ & 3 \\
\hline 2 & $\begin{array}{l}\text { Western Russia, Kursk province, Central Chernozem } \\
\text { Natural Reserve, cluster "Streletskaya Steppe" }\end{array}$ & $51^{\circ} 34^{\prime} \mathrm{N} 36^{\circ} 06^{\prime} \mathrm{E}$ & $3(3)$ & 1 \\
\hline 3 & $\begin{array}{l}\text { Western Russia, Kursk province, Dmitriyev district, } \\
\text { Deryugino village }\end{array}$ & $52^{\circ} 13^{\prime} \mathrm{N} 35^{\circ} 04^{\prime} \mathrm{E}$ & 4(4) & 1 \\
\hline 4 & $\begin{array}{l}\text { Western Russia, Kursk province, Ponyri district, } \\
\text { Olkhovatka village }\end{array}$ & $52^{\circ} 15^{\prime} \mathrm{N} 36^{\circ} 08^{\prime} \mathrm{E}$ & 1(1) & 1 \\
\hline 5 & $\begin{array}{l}\text { Western Russia, Oryol province, Livny city northern } \\
\text { vicinities }\end{array}$ & $52^{\circ} 27^{\prime} \mathrm{N} 37^{\circ} 38^{\prime} \mathrm{E}$ & 1(1) & 1 \\
\hline 6 & $\begin{array}{l}\text { Western Russia, Oryol province, } 5 \mathrm{~km} \text { E from Mtsensk } \\
\text { city }\end{array}$ & $53^{\circ} 16^{\prime} \mathrm{N} 36^{\circ} 39^{\prime} \mathrm{E}$ & $3(3)$ & 3 \\
\hline 7 & $\begin{array}{l}\text { Central Russia, Tula province, Efremov city western } \\
\text { vicinities }\end{array}$ & $53^{\circ} 09^{\prime} \mathrm{N} 38^{\circ} 03^{\prime} \mathrm{E}$ & $1(1)$ & 1 \\
\hline 8 & $\begin{array}{l}\text { Western Russia, Voronezh province, Verkhnyaya } \\
\text { Khava district, Belovo village }\end{array}$ & $51^{\circ} 54^{\prime} \mathrm{N} 39^{\circ} 48^{\prime} \mathrm{E}$ & $4(3)$ & 3 \\
\hline 9 & $\begin{array}{l}\text { Western Russia, Lipetsk province, Krasnoye district, } \\
\text { Nikolskoye village }\end{array}$ & $52^{\circ} 58^{\prime} \mathrm{N} 38^{\circ} 33^{\prime} \mathrm{E}$ & $5(5)$ & $1(1)$ \\
\hline 10 & Central Russia, Moscow city and the city suburbs & $\mid \begin{array}{l}55^{\circ} 38^{\prime} \mathrm{N} 37^{\circ} 43^{\prime} \mathrm{E} \\
55^{\circ} 36^{\prime} \mathrm{N} 38^{\circ} 04^{\prime} \mathrm{E}\end{array}$ & $5(1)$ & 2 \\
\hline
\end{tabular}

* total number of analyzed animals including individuals studied earlier (Feoktistova et al., 2017). Number of individuals captured during 2017 - 2018 surveys is given in parenthesis. 
Phylogenetic analysis were done for the concatenated (1803 bp) sequences of cyt $b$ (924 bp) and the mtDNA control region (879 bp) and for cyt $b$ fragment of 904 bp length separately. For the former 18 newly described haplotypes (Table 2) were added with 25 sequences described earlier for Western and Center Russia, Ural, Crimea and Northern

Table 2. The definition of new described haplotypes of concatenated mtDNA fragment (1803 bp) as a combination of cytb gene and control region sequences deposited in Genbank

\begin{tabular}{l|l}
\multicolumn{1}{c}{ Region } & Genbank (cyt $b+$ d-loop) \\
\hline W. Russia & MK202461 + MK202475 \\
\hline W. Russia & MK202462 + MK202476 \\
\hline W. Russia & MK202463 + MK202477 \\
\hline W. Russia & MK202464 + MK202478 \\
\hline W. Russia & MK202465+ MK202479 \\
\hline W. Russia & MK202458+ MK202474 \\
\hline W. Russia & MK202459+ MK202474 \\
\hline W. Russia & MK202460+ MK202474 \\
\hline W. Russia & MK202456+ MK202472 \\
\hline C. Russia & MK202457+ MK202473 \\
\hline Volga Region & MK202455+ KF271766 \\
\hline Crimea & MK202453+ MK202471 \\
\hline Crimea & MK202454+ KF271779 \\
\hline N. Kazakhstan & MK202466+ KY795998 \\
\hline N. Kazakhstan & MK202467+ KY748092 \\
\hline N. Kazakhstan & MK202468+ KY748092 \\
\hline Bulgaria & MK202469 + MK202480
\end{tabular}

Note. In addition, the haplotype of hamster from locality "4" differed from MK202462 (cytb) and MK202475 (control region) by single substitutions (E1 phylogroup) was used in analysis.

Kazakhstan (Tables 1 and 2 in Feoktistova et al., 2017). In case of cytb fragment only analysis the new and earlier described haplotypes from these territories were also added with E1 sequences of hamster from Poland - AJ633782 (Neumann et al, 2005) and EU107528-535 (Banaszek et al., 2010).

The homologous fragments of mitochondrial genome of Cricetulus migratorius (GenBank KT918407) were used as an outgroup in both analyses.

To study phylogenetic relations between haplotypes we used the Bayesian algorithm realized in $\mathrm{MrBa}-$ yes 3.2 software (Huelsenbeck, Ronquist, 2001; Ronquist, Huelsenbeck, 2003) for 5000000 iterations and 100000 iterations of burn in. For both concatenated cyt $b$ and control region sequences and for $904 \mathrm{bp}$ cyt $b$ fragments only $\mathrm{HKY}+\mathrm{I}+\mathrm{G}$ model parameters were used. This model was chosen based on the analysis using MrModeltest 2.3 software (Nylander, 2004) and Akaike information criterion. To estimate within- and between-groups averaged genetic distances we used MEGA7.0.20 software (Tamura et al., 2013; Kumar et al., 2016).

\section{RESULTS AND DISCUSSION}

In Bryansk province in the vicinity of the State Reserve "Bryansky Les" (point 1 on Fig. 1), in 2004 - 2005 the Common hamster was registered at 10 locations (district of Sevsk, Komarichi, Trubchevsk districts) (Mishta, Sitnikova, 2005). When we reexamining the same points in 2017, only one location inhabited by the Common hamster was found (Fig. 1).

The Common hamster is at the list of the fauna of Central Chernozem State Natural Reserve (Kursk province) and was abundant and pest till the end of 1950th. Later only solitary individuals were recorded (in 2002, 2006, 2008, 2014) in the Reserve. In 2017 2018 we caught 3 hamsters in the Reserve cluster «Streletskaya Steppe» (Southern outskirts of the Kursk city, point 2 on Fig. 1). There are sparse wild pear, apple, plum trees 


\section{ABOUT THE BORDER BETWEEN TWO PHYLOGROUPS}

and berry bushes in the virgin steppe. The chernozem (black soil) covered with tall grass (up to $1 \mathrm{~m}$ ) and with last years dry grass carpet (up to $30 \mathrm{~cm}$ deep).

In general, the number of the Common hamster in all 7 studied Russian provinces at the last 50 years has significantly declined. Most of the locals never met the Common hamster. However, in the 50 - 60th hamsters populated almost all crop fields but active harvesting of this species was not typical here (Neronov, 1965). Currently in our study region we note, as a result of the species synurbization process, Common hamster presence mainly in so called 'dacha' (summer houses with gardens, a sort of suburban or urban allotments or community gardens). Here the hamsters can reach a significant number bringing a lot of troubles for garden owners, especially in the harvesting season.

The phylogenetic analysis based on newly described and earlier known haplotypes confirmed both the existence of two different well supported clades corresponding with E1 and E0 phylogroups and affiliation of new sequences with one or another of the phylogroups (Fig. 2). The analysis based on cyt b haplotype samples added with Caucasian, North and Pannonia sequences (results is not shown) confirmed that sample from Bulgaria belonged to Pannonia phylogroup, which is the first evidence of this phylogroup presence in Bulgaria. The occurrence of E0 and E1 lineages on studied territory of Western and Central parts of European Russia is shown on Figure 1. The localities 1, 3, and 4 populate by E1 lineage only while hamsters belonging to E0 inhabited the localities 2, 5, and $7-10$. The distance between locality 2 (where three individuals of E0 haplotype found) and locality 4 (the individual of E1 lineage haplotype) is $75 \mathrm{~km}$, and distance between locality 2 and locality 3 (four individuals of E1 lineage) $-100 \mathrm{~km}$. At the same time at locality 6 (near Mtsensk city in Oryol province), two hamsters captured belonged to E1 but another animal belonged to E0 lineage captured at the same locality and habitat.

Thus, we had a case of sympatry. For other localities the distance between the known localities of lineages E0 and E1 exceed $75 \mathrm{~km}$. Based on our findings we may assume E1/E0 lineages boundary to run from Ukrainian Sumy province to North-East dividing the Russian Kursk and Oryol provinces (Fig. 1). We suggest this division between these phylogroups takes place at Ukraine, too. Northern part of Sumy province the most probably populated with E1, Southern part - with E0 lineage. In our opinion, the probable division line in Ukraine next runs from Sumy province to South in the direction of Crimea so Eastern and South-Eastern regions of Ukraine possibly are inhabited by hamsters of the E0 lineage.

All 64 hamsters captured in Crimea belong to E0 phylogroup. Phylogenetic analysis based on concatenated cyt $b$ and control region fragments showed that seven of eight haplotypes known for different areas of Crimea - from Razdolne district at northern part of the peninsula to Kirovsky district (area adjacent to Stary Krym and Feodosia cities) at the South-East - form a separated well supported branch (Fig. 2 A). Only single hamster captured at the extreme eastern part of the Crimea, at Kerch peninsula, had a haplotype more similar to that known from Kursk and Oryol provinces of Western Russia. Based on earlier used method (Feoktistova et al., 2017) of divergence time estimation (BEAST v2.4.5 software (Bouckaert et al., 2014) relaxed clock and Yule model, the results are not shown) and on our preliminary estimation of E1/E0 TMRCA as 67 kya (95\% HPD 
37 - 104 kya, (Feoktistova et al., 2017), TMRCA for the 7 mentioned above Crimean haplotypes may estimated as about $15-20$ kya.
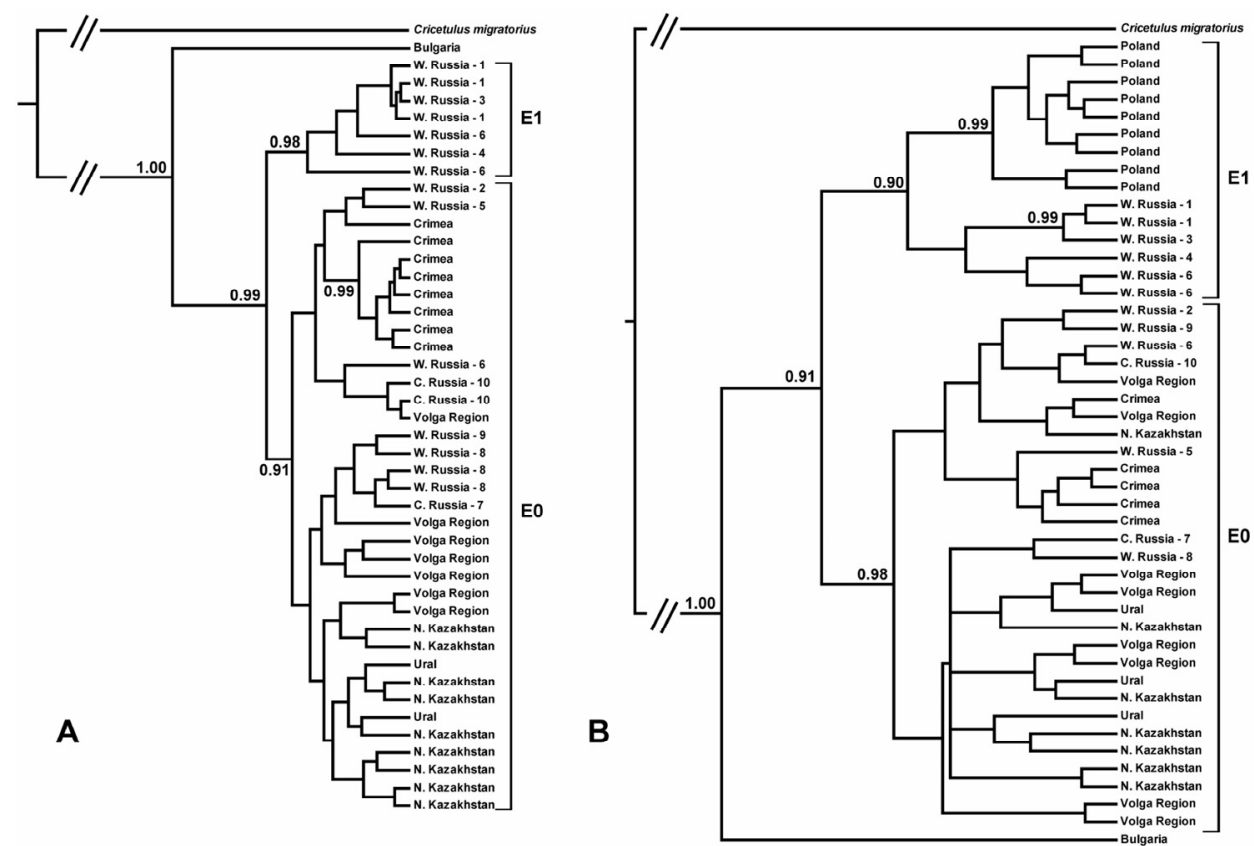

Fig. 2. The Bayesian phylograms of the concatenated sequences of cyt $b$ and control region (1803 bp) (A) and 904 bp cytb fragment only (B) haplotypes. The node support is shown for values $=0.90$ and for nodes of three or more haplotypes only. For number of localities of Western and Central Russia see Table 1

At present, the Crimea peninsula is connected with mainland (South Ukraine) through Perekop isthmus. Also, Chongar peninsula and Arabat spit located between Crimea and mainland are crossed with shallow channels no more than $100 \mathrm{~m}$ wide each. Such narrow water area is not a real barrier for the Common hamster. Nevertheless, the existence of separated Crimean subclade suggests that recent Crimean Common hamster population formed (at least partly) independently. First (and main) migration wave might take place during Black Sea New-Euxinian regression stage, when the Sea of Azov basin dried up and modern Crimean peninsula was a mainland part open for the Common hamster migration from periglacial steppes of modern Ukraine mainland. New-Euxinian regression was in LGM (about $25-15$ kya) but it the final stage ended about 9 kya. Later, during the Atlantic, sea level gradually increased but was below modern and Crimea remained part of mainland (Ivanov et al., 2018). Former steppes were forested what caused the disintegration of the Common hamster range and isolated Crimean populations from mainland. Presumably, at that time the formation of the Crimean common hamster population, represented mainly by relatively separate lineages, had completed. 


\section{ABOUT THE BORDER BETWEEN TWO PHYLOGROUPS}

In the end Atlantic sea lever rose higher of the modern level and separated Crimea from mainland where in Subboreal period have spread steppes (Mishchenko et al., 2018) and the Common hamster range.

The hamsters belonging to recent mainland E0 lineages, to our opinion, appeared in the Crimea later, as a secondary migration wave. Although till present this haplotype was found only in easternmost part of Crimea, it is doubtful that the second wave of migrants reached the Crimea crossing the Kerch strait. This strait, which is more than $4 \mathrm{~km}$ wide in its most narrowness at present, never dried up during the last 20 kya. Also, it is presumed that the east (Caucasian) coast of the strait is populated not by E0 but by another phylogroup we named Caucasian. Probably, the second wave of hamster's migration to Crimea also occurred from the North, from modern South or South-Eastern Ukraine. The Phanagorian regression that took place about 2500 years ago (Semikolennykh et al., 2018) may be a suitable time for it. Then the sea level fell by about $5 \mathrm{~m}$, which led to the disappearance of the shallow parts of the Sea of Azov, including the Sivash channels (Ivanov et al., 2018; Mishchenko et al., 2018; Semikolennykh et al., 2018). In any case the presence in Crimea E0 phylogenetic lineages (either native or invasive) only suggests that Eastern and South-Eastern parts of Ukraine, from Southern Sumy province to Dnieper mouth, is populated by E0 phylogroup hamsters.

In our previous study the mean of within-group distance for $904 \mathrm{bp}$ cyt $b$ fragment was estimated for 19 E0 group haplotypes revealed in Russia and Northern Kazakhstan as $0.444 \%$ (Feoktistova et al., 2017). Now, based on 30 E0 haplotypes, this value was estimated as $0.450 \%$. Thus, the known diversity of this group increased slightly despite on new described sequences for very distanced locations (Western Russia and Northern Kazakhstan). On the contrary, the increase of E1 group sample from 10 (nine from Poland and one from Western Russia) to 15 (5 new sequences were revealed from Western Russia) led to the significant increasing of the within-group distance mean - from $0.334 \%$ to $0.440 \%$. Thus, one may expect that E1 phylogroup diversity would increase more after new samples from Ukraine, Belarus, Western Russia would be analyzed.

On the phylogenetic tree the subclade of six cytb E1 haplotypes known from Russia is not supported. On the contrary, nine cyt $\mathrm{b}$ haplotypes originated from Poland formed $\mathrm{a}$ well supported subclade (Fig. 2 B). The mean of MRCA time for this clade may be preliminary estimated as enough long - about $30-35$ kya. The existence of subclades within both E1 and E0 phylogroups suggests that diversification of phylogenetic lineages of the Common hamster in Eastern Europe may resulted from not single but multiple climatic events during second half of Late Pleistocene. Different populations could survive in different refugia and/or isolates such it is presumed for Crimea. The phylogeographical structure of the Common hamster in Eastern Europe may be more complicated that it is known for today.

\section{Acknowledgments}

We thank Nedko Nedyalkov (National Museum of Natural History of Bulgaria) for providing a sample of Common hamster from Bulgaria.

This work was supported by the Russian Foundation for Basic Research (project no. 17-04-01061) and by the Presidium of the Russian Academy of Sciences (project no. 41 "Biodiversity of natural systems and biological resources of Russia"). 
Natalia Yu. Feoktistova, Ilya G.'Meschersky, Pavel L. Bogomolov et al.

\section{REFERENCES}

Banaszek A., Jadwiszczak K. A., Ratkiewicz M., Ziomek J., Neumann K. Population structure, colonization processes and barriers for dispersal in Polish Common hamsters (Cricetus cricetus). J. of Zoological Systematics and Evolutionary Research, 2010, vol. 48, iss. 2, pp. 151-158.

Banaszek A., Ziomek J., Jadwiszczak K. A., Kaczyńska E., Mirski P. Identification of the barrier to gene flow between phylogeographic lineages of the Common hamster Cricetus cricetus. Acta Theriologica, 2012, vol. 57, iss. 3, pp. 195-204. DOI: https://doi.org/10.1007/s13364-012-0075-z

Bouckaert R., Heled J., Kühnert D., Vaughan T., Wu C.-H., Xie D., Suchard M. A., Rambaut A., Drummond A. J. BEAST 2: A software platform for Bayesian evolutionary analysis. PLoS Computational Biology, 2014, vol. 10, no. 4, pp. e1003537. DOI: https://doi.org/10.1371/journal. pcbi. 1003537

Feoktistova N. Y., Meschersky I. G., Surov A. V., Bogomolov P. L., Tovpinetz N. N., Poplavskaya N. S. Genetic structure of urban population of the Common hamster (Cricetus cricetus). Russian J. of Genetics, 2016, vol. 52, iss. 2, pp. 194-203.

Feoktistova N. Yu., Meschersky I. G., Bogomolov P. L., Sayan A. S., Poplavskaya N. S., Surov A. V. Phylogeographic structure of the Common hamster (Cricetus cricetus L.): Late Pleistocene connections between Caucasus and Western European populations. PLoS ONE, 2017, vol. 12, no. 11, pp. e0187527. DOI: https://doi.org/10.1371/journal.pone.0187527

Hall T. A. BioEdit: a user-friendly biological sequence alignment editor and analysis program for Windows 95/98/NT. Nucleic Acids Symposium Series, 1999, vol. 41, pp. 95-98.

Huelsenbeck J. P., Ronquist F. MRBAYES: Bayesian inference of phylogeny. Bioinformatics, 2001, vol. 17, iss. 8, pp. 754-755.

Ivanov V. V., Korotaev V. N., Myslivets V. I., Porotov A. V., Pronin A. A., RimskyKorsakov N. A., Tikhonova N. F. Geophysical and hydrographical surveys at the eastern shelf of the Crimea peninsula (Feodosiya-Kerch-Anapa). Oceanological Research, 2018, vol. 46, no.1, pp. 82-101.

Korbut Z., Rusin M. Yu., Banaszek A. The distribution of the Common hamster (Cricetus cricetus) in western Ukraine. Zoologica Poloniae, 2013, vol. 58, iss. 3-4, pp. 99-112.

Kumar S., Stecher G., Tamura K. MEGA7: Molecular Evolutionary Genetics Analysis version 7.0 for bigger datasets. Molecular Biology and Evolution, 2016, vol. 33, iss. 7, pp. 1870-1874.

Mishta A. V., Sitnikova E. F. Obyknovenny homyak na yugo-vostoke Bryanskoy oblasti [The Common hamster in the SE of Bryansk province]. Y. P. Fedotov, ed. In: Izuchenie i okhrana biologicheskogo raznoobrazia Bryanskoy oblasti [Study and conservation of biodiversity of Bryansk province]. Trubchevsk, Kirillitsa, 2005, vol. 1, pp. 160-162 (in Russian).

Mishchenko A. A., Volkova T. A., Minenkova V. V., Antiptseva Yu. O. The Black and the Azov Seas and their Coasts Paleogeography in the Pleistocene and Holocene Periods (within the Krasnodar Region). Dagestan State Pedagogical University. Journal. Natural and Exact Sciences, 2018, vol. 12, no. 1, pp. 65-72 (in Russian). DOI: https://doi.org/10.31161/1995-0675-2018-12-1-65-72

Neronov V. M. Issledovanie struktury arealov obyknovennogo khomyaka $i$ vodyanoy krisy na territprii SSSR [Study of the range structure of Common hamster and European water vole in the USSR]. Thesis Diss. Cand. Sci. (Geogr.). Moscow, 1965. 24 p. (in Russian).

Neumann K., Michaux J. R., Maak S., Jansman H. A., Kayser A., Mundt G., Gattermann R. Genetic spatial structure of European Common hamsters (Cricetus cricetus) - a result of repeated range expansion and demographic bottlenecks. Molecular Ecology, 2005, vol. 14, iss. 5, pp. 1473-1483.

Nylander J. A. A. MrModeltest v2. Program distributed by the author. Uppsala, Evolutionary Biology Centre, 2004.

Tamura K., Stecher G., Peterson D., Filipski A., Kumar S. MEGA6: Molecular Evolutionary Genetics Analysis Version 6.0. Molecular Biology and Evolution, 2013, vol. 30, iss. 12, pp. 2725-2729. 


\section{ABOUT THE BORDER BETWEEN TWO PHYLOGROUPS}

Ronquist F., Huelsenbeck J. P. MRBAYES 3: Bayesian phylogenetic inference under mixed models. Bioinformatics, 2003, vol. 19, iss. 12, pp.1572-1574.

Semikolennykh D. V., Arslanov Kh. A., Ignatov E. I., Luksha V. L. Evolution of natural environment of the Kerch strait area during recent 25 thousand years. Vestnik Moskovskogo Universiteta, Ser. 5. Geography, 2018, vol. 3, pp. 55-61.

Surov A., Banaszek A., Bogomolov P., Feoktistova N., Monecke S. Dramatic global decrease in the range and reproduction rate of the European hamster Cricetus cricetus. Endangered Species Ressearch, 2016, vol. 31, pp. 119-145. DOI: https://doi.org/10.3354/esr00749 
Natalia Yu. Feoktistova, Ilya G.'Meschersky, Pavel L. Bogomolov et al.

\title{
К ВОПРОСУ О ГРАНИЦЕ МЕЖДУ ДВУМЯ ФИЛОГРУППАМИ ОБЫКНОВЕННОГО ХОМЯКА (CRICETUS CRICETUS) (CRICETINAE, RODENTIA)
}

\author{
Н. Ю. Феоктистова ${ }^{1}$, И. Г. Мещерский ${ }^{1}$, П. Л. Богомолов ${ }^{1}$, С. И. Мещерский ${ }^{1}$, \\ А. С. Саян ${ }^{1}$, Е. Ф. Ситникова ${ }^{2}$, А. А. Власов ${ }^{3}$, О. П. Власова ${ }^{3}$, А. В. Суров ${ }^{1}$ \\ ${ }^{1}$ Институт проблем экологии и эволюичи им. А. Н. Северияова РАН \\ Россия, 117071, Москва, Ленинский просп., 33 \\ E-mail:feoktistovanyu@gmail.com \\ ${ }^{2}$ Биосферный заповедник «Брянский Лес» \\ Россия, 242180, Брянская область, Суземский район, станции Нерусса \\ ${ }^{3}$ Центрально-Чернозёмный государственный природный биосферный заповедник \\ имени профессора В. В. Алёхина \\ Россия, 305528, Курская область, Курский район, п/о Заповедное
}

Поступила в редакцию 17.08.2018 г., после доработки 21.09.2018 г., принята 2.10.2018 г.

Feoktistova N. Yu., Meschersky I. G., Bogomolov P. L., Meschersky S. I., Sayan A. S., Sitnikova E. F., Vlasov A. A., Vlasova O. P., Surov A. V. About the Border between Two Phylogroups of the Common Hamster (Cricetus cricetus) (Cricetinae, Rodentia) [Феоктистова H. Ю., Мещерский И. Г., Богомолов П. Л., Мещерский С. И., Саян А. С., Ситникова Е. Ф., Власов А. А., Власова О. П., Суров А. В. К вопросу о границе между двумя филогруппами обыкновенного хомяка (Cricetus cricetus) (Cricetinae, Rodentia)] // Поволжский экологический журнал. 2018. № 4. C. 485 - 494. DOI: https://doi.org/10.18500/1684-7318-2018-4-485-494

Обыкновенных хомяк (Cricetus cricetus) - грызун с одним из самых крупных ареалов среди млекопитающих (около 6 миллионов км²). Ранее, в Западной Европе, на Украине и в Брянской области было обнаружено четыре филогеографические линии: «North», «Pannonia», E1 и E0. Е1 была выявлена в Юго-Восточной Польше и на Западной Украине. Предпринимались попытки найти зону контакта между филогруппами E1 и «Рannonia», но они не увенчались успехом, хотя расстояние между крайними известными точками обитания этих филогрупп не превышало 20 км. Существует ли зона симпатрия групп Е1 и Е0? Для ответа на этот вопрос было проведено маршрутное обследование с отловами животных в Московской, Тульской, Брянской, Орловской, Курской, Липецкой и Воронежской областях. По последовательности контрольной области мтДНК и гена суt $b$, выделенных из образцов ткани уха, определяли принадлежность к той или иной филогруппе. В окрестностях г. Мценск (Орловская область) нами впервые обнаружена симпатрия филогрупп Е0 и Е1. Здесь в одном биотопе обитали хомяки, принадлежащие к обеим филогруппам. Однако пока это единственный случай, в других локалитетах они разделены расстоянием не менее 75 км. Гипотетически граница Е1/Е0 проходит от Сумской области Украины на северо-восток, по линии, разделяющей Курскую и Орловскую области. Существование подклад внутри филогрупп Е1 и Е0 позволяет предполагать, что диверсификация филогенетических линий обыкновенного хомяка в Восточной Европе может быть результатом не единичных, а множественных климатических событий во второй половине позднего плейстоцена. Филогеографическая структура вида в Восточной Европе может оказаться более сложной, чем считалось до настоящего времени.

Ключевые слова: обыкновенный хомяк, филогеография, мтДНК, контрольный регион, генетические линии, симпатрия.

DOI: https://doi.org/10.18500/1684-7318-2018-4-485-494

Благодарности. Работа выполнена при финансовой поддержке Российского фонда фундаментальных исследований (проект № 17-04-01061) и Программы Президиума РАН (проект № 41 «Биоразнообразие природных систем и биологических ресурсов России»). 